Subscriber access provided by SDIS @ INRS | http://sdis.inrs.ca

\title{
Article
}

\section{Covalent Immobilization of laccase onto nanofibrous membrane for degradation of pharmaceutical residues in water}

\author{
Mehrdad Taheran, Mitra Naghdi, Satinder Kaur Brar, Emile \\ J Knystautas, Mausam Verma, and Rao Y Surampalli \\ ACS Sustainable Chem. Eng., Just Accepted Manuscript • DOI: 10.1021/ \\ acssuschemeng.7b02465 - Publication Date (Web): 13 Oct 2017
}

Downloaded from http://pubs.acs.org on October 17, 2017

\section{Just Accepted}

\begin{abstract}
"Just Accepted" manuscripts have been peer-reviewed and accepted for publication. They are posted online prior to technical editing, formatting for publication and author proofing. The American Chemical Society provides "Just Accepted" as a free service to the research community to expedite the dissemination of scientific material as soon as possible after acceptance. "Just Accepted" manuscripts appear in full in PDF format accompanied by an HTML abstract. "Just Accepted" manuscripts have been fully peer reviewed, but should not be considered the official version of record. They are accessible to all readers and citable by the Digital Object Identifier (DOI®). "Just Accepted" is an optional service offered to authors. Therefore, the "Just Accepted" Web site may not include all articles that will be published in the journal. After a manuscript is technically edited and formatted, it will be removed from the "Just Accepted" Web site and published as an ASAP article. Note that technical editing may introduce minor changes to the manuscript text and/or graphics which could affect content, and all legal disclaimers and ethical guidelines that apply to the journal pertain. ACS cannot be held responsible for errors or consequences arising from the use of information contained in these "Just Accepted" manuscripts.
\end{abstract}




\title{
Covalent Immobilization of laccase onto nanofibrous membrane for
} degradation of pharmaceutical residues in water

\author{
M. Taheran ${ }^{1}$, M. Naghdi ${ }^{1}$, S. K. Brar ${ }^{1 *}$, E. J. Knystautas ${ }^{2}$, M. Verma ${ }^{3}$, R.Y. Surampalli ${ }^{4}$ \\ ${ }^{1}$ INRS-ETE, Université du Québec, 490, Rue de la Couronne, Québec, Canada G1K 9A9 \\ ${ }^{2}$ Département de Physique, Université Laval, Québec G1K 7P4, Canada \\ ${ }^{3} \mathrm{CO}_{2}$ Solutions Inc., 2300, rue Jean-Perrin, Québec, Québec G2C 1T9 Canada \\ ${ }^{4}$ Department of Civil Engineering, University of Nebraska-Lincoln, N104 SEC PO Box 886105, \\ Lincoln, NE 68588-6105, US \\ (*Phone: 1418654 3116; Fax: 1418654 2600; E-mail: satinder.brar@ete.inrs.ca)
}

\begin{abstract}
Enzymatic degradation with ligninolytic enzyme e.g. laccase is a potential green solution for removal of pharmaceutical compounds that are released into the environment through wastewater effluent. However, the deficiencies of using the enzyme in its free forms, such as reusability and stability should be addressed before industrial applications. In this study, laccase was immobilized onto tailor-made Polyacrylonitrile-biochar composite nanofibrous membrane through covalent bonding and the parameters of immobilization were optimized. The obtained biocatalyst was utilized for removal of chlortetracycline (CTC), carbamazepine (CBZ) and diclofenac (DCF) at an environmentally-relevant concentration in batch mode. These pharmaceutical compounds represented three main categories of pharmaceutical compounds i.e. antibiotics, antidepressant, and anti-inflammatory. The results showed that the immobilized laccase has improved storage, temperature and $\mathrm{pH}$ stability compared to free laccase. Also, it maintained more than $17 \%$ of its initial activity after 10 cycles of ABTS oxidation which indicated improved reusability of the enzyme. Using immobilized laccase for degradation of three pharmaceutical compounds in batch experiments exhibited $72.7 \%, 63.3 \%$ and $48.6 \%$ degradation efficiency for DCF, CTC, and CBZ, respectively after 8 hours of reaction. The decreasing trend of adsorption extent during reaction time for all compounds confirmed the regenerative effect of laccase on adsorption sites of biochar.
\end{abstract}

Keywords: Laccase, Biodegradation, Wastewater, Pharmaceutical compounds 


\section{Introduction}

The occurrence of pharmaceutically active compounds (PhACs) in different environmental compartments has attracted attention in the recent decade due to their potential effects on humans and other organisms even at very low concentrations ${ }^{1}$. For example, there are reports on histological alteration in gills of fish caused by tetracycline compounds ${ }^{2}$. Also, there is evidence on the development of antibiotic resistance among bacteria antibiotics ${ }^{3}$. After the intake of PhACs by human or animals, they leave the body as intact substances or metabolites through urine and feces. Since wastewater treatment plants (WWTPs) are not able to inefficiently remove all of these micropollutants, they enter the environment by releasing the effluent into the surface waters ${ }^{4}$. Therefore, an increasing interest was shown by researchers and industries in recent years to develop methods to achieve efficient removal of these compounds. Till date, versatile methods e.g. physical, biological and chemical processes have been proposed and investigated for removal of PhACs from water and wastewater. However, several issues, such as the production of toxic by-products and generation of a waste stream need to be addressed before implementing these methods at large scale ${ }^{5}$.

White-rot fungi (WRF) proved to have the capability of breaking organic pollutants into less harmful products under mild conditions. They attack these compounds through the production of intracellular enzymes (cytochrome P450) and extracellular ligninolytic enzymes e.g. laccases and peroxidases ${ }^{6}$. The extracted ligninolytic enzymes, especially laccases, for treatment of wastewater is a promising option due to their oxidizing capability towards a wide range of micropollutants and their lower environmental impact ${ }^{7}$. There are numerous reports on the efficient degradation of different classes of PhACs e.g. antibiotics, anti-inflammatory, psychiatric, etc. by using laccase in its free form ${ }^{7-8}$. However, using free laccase involves reusability problem and also lower stability which increases the cost of operation ${ }^{1}$. Immobilization of enzyme onto porous membranes is a promising approach to push back the mentioned problems and achieve longer shelf-life and stability against $\mathrm{pH}$ and temperature ${ }^{9}$.

There are many research works in the literature reporting immobilized laccase for removal of pollutants but in most of them, purified laccase was used while using crude can be more economical. Furthermore, the reported concentrations of micropollutants in the literature $(>20$ ppm) is far higher than their real concentrations in municipal wastewater. 
The main objective of this research was to evaluate the potential of immobilized laccase on the degradation of a mixture of three representatives of $\mathrm{PhACs}$, namely antibacterial chlortetracycline (CTC), anti-inflammatory diclofenac (DCF) and antiepileptic carbamazepine (CBZ) at an environmentally relevant concentration. These PhACs were selected due to their high consumption and widespread occurrence in WWTPs and also their different physicochemical properties (Table 1) that affect their fate in WWTPs. The membrane for immobilization of enzyme was a composite of Polyacrylonitrile (PAN) and biochar adsorbent particles which were processed onto nanofibrous membrane through electrospinning. Using biochar for treatment of wastewater is of high interest due to its interesting physico-chemical properties, availability, low cost and role in value-addition to wooden residues. In this work, the activated biochar was entrapped into the nanofibers to create the adsorption capability in the membrane and increase the contact time between the immobilized enzyme and target pollutants 10. The employed laccase was produced by growing a strain of WRF on a cost-effective substrate and it was covalently bonded to the membrane through a method that has not been reported before for laccase immobilization.

Table 1: Properties of pharmaceutical compounds investigated in this research

\begin{tabular}{|c|c|c|c|c|c|c|}
\hline Compound & Molecular structure & Classification & Log Kow & pKa & Characteristics & Ref. \\
\hline Chlortetracycline (CTC) & & Antibacterial & -3.60 & $\begin{array}{c}3.3,7.4 \\
\& 9.3\end{array}$ & $\begin{array}{l}\text { toxicity for environment, } \\
\text { antibacterial resistance }\end{array}$ & 11 \\
\hline Carbamazepine (CBZ) & & $\begin{array}{l}\text { Anticonvulsant } \\
\text { Antiepileptic }\end{array}$ & 2.45 & - & $\begin{array}{c}\text { Stable structure, low removal } \\
\text { by activated sludge }\end{array}$ & 4 \\
\hline Diclofenac (DCF) & & $\begin{array}{l}\text { Anti- } \\
\text { inflammatory }\end{array}$ & 4.51 & 4.15 & $\begin{array}{l}\text { Worldwide presence in } \\
\text { treatment plants, low } \\
\text { removal by activated sludge }\end{array}$ & 4 \\
\hline
\end{tabular}

\section{Materials and methods}

\section{Chemicals}

2, 2'-azino-bis (3-ethyl-benzothiazoline-6-sulphonic acid: ABTS) was provided by SigmaAldrich (Oakville, Canada). Tween 80, methanol and glutaraldehyde (purity $>99 \%$ ) were purchased from Fisher scientific (Ottawa, Canada). HPLC grade water was produced in the laboratory using milli-Q/Milli-Ro system (Millipore, USA). Polyacrylonitrile (PAN), with an 
average molecular weight of $1.5 \times 10^{5}(\mathrm{~g} / \mathrm{mol})$, was purchased from Scientific Polymer Product Company (USA). Sodium hydroxide, hydrogen chloride and N, N'-Dimethyl-Formamide (DMF) of analytical grade was purchased from Fisher Scientific (USA). Chlortetracycline (CTC, purity $>$ 97\%) was provided by Toronto Research Chemicals (TRC-Canada). Carbamazepine (CBZ, purity $\geq 99 \%$ ) was purchased from Sigma-Aldrich (Oakville, ON, Canada). Diclofenac sodium salt (DCF, purity $\geq 98 \%$ ) was purchased from Fisher Scientific (Ottawa, ON, Canada). Apple pomace was provided by Vergers Paul Jodoin Inc., (Quebec, Canada). Biochar was provided by Pyrovac Inc. (Canada) and it originated from $80 \%$ of pine white wood and $20 \%$ of spruce and fir. This biochar was produced at $525 \pm 1{ }^{\circ} \mathrm{C}$ under atmospheric pressure for 2 minutes. Biochar was activated through alkali treatment at $800{ }^{\circ} \mathrm{C}$. The detailed process and the properties of activated biochar have been discussed elsewhere ${ }^{12}$.

\section{Preparation of inoculum}

Fungus, Trametes versicolor (ATCC 20869) was grown aerobically in potato dextrose broth (PDB) liquid medium inoculated with lyophilized strain and then the flask was incubated in an orbital shaker at $30 \pm 1{ }^{\circ} \mathrm{C}$ and $150 \mathrm{rpm}$ for 7 days. Later, $100 \mu 1$ of PDB medium was used to inoculate the potato dextrose agar (PDA) plates and the plates were kept in a static incubator at $30 \pm 1^{\circ} \mathrm{C}$ for 9 days.

\section{Solid-state fermentation}

For the production of laccase by $T$. versicolor, apple pomace (with $70 \mathrm{wt} \%$ moisture and $\mathrm{pH} 4.5$ ) was used as a cost-effective solid substrate. About 40 grams of apple pomace was added to a 500 $\mathrm{mL}$ flask along with $0.5 \% \mathrm{v} / \mathrm{w}$ Tween 80 as inducer, mixed thoroughly and autoclaved at $121 \pm 1$ ${ }^{\circ} \mathrm{C}$ for $30 \mathrm{~min}$. Later, the substrate was inoculated with the biomass content of one Petri plate obtained in the previous step, and it was kept in a static incubator at $30 \pm 1^{\circ} \mathrm{C}$ for 15 days.

\section{Enzyme extraction and assay}

One gram of fermented sample, prepared in the previous step, was added to $20 \mathrm{~mL}$ of sodium phosphate buffer (50 mM, pH 4.5), mixed thoroughly for $1 \mathrm{~h}$ at $35 \pm 1{ }^{\circ} \mathrm{C}$ and then centrifuged at $7,000 \times \mathrm{g}$ for $30 \mathrm{~min}$. Then, the supernatant was collected and its relative laccase activity was analyzed by monitoring the oxidation of ABTS at $420 \mathrm{~nm}\left(\varepsilon_{420}=36,000 \mathrm{M}^{-1} \mathrm{~cm}^{-1}\right)$ at $\mathrm{pH}=4.5$ and 
$45 \pm 1^{\circ} \mathrm{C}$ using a Varian Cary-50 UV-VIS spectrophotometer. Each unit of laccase was defined as the amount of enzyme required to oxidize one micromole of ABTS within one minute under assay conditions. To determine the laccase activity of the immobilized enzyme, $20 \mathrm{mg}$ of the immobilized sample was mixed with $4 \mathrm{~mL}$ sodium phosphate buffer (pH 3.5) containing $0.5 \mathrm{mM}$ ABTS and after 3 min of incubation at $45^{\circ} \mathrm{C}$, the absorbance at $420 \mathrm{~nm}$ was recorded. The measurement was performed in triplicate and the averages have been illustrated along with the related standard deviations.

\section{Preparation of PAN-biochar membrane}

About $2 \mathrm{~g}$ of PAN was dissolved in DMF (12\%, w/v) and stirred on a magnetic stirrer for one day. Activated biochar at the ratio of $1.5 \%(w / w)$ of PAN was introduced to the solution and the mixture was stirred for another day. PAN-biochar nanofibrous membrane was produced through electrospinning process by using a rotary drum collector (length $=25 \mathrm{~cm}$, diameter $=10 \mathrm{~cm}$ ) at 25 ${ }^{\circ} \mathrm{C}$ and $35 \%$ relative humidity. The electric field strength, flow rate and rotational speed of collector were adjusted to $1.4 \mathrm{KV} / \mathrm{cm}, 3 \mathrm{~mL} / \mathrm{h}$, and $400 \mathrm{rpm}$, respectively. Also, the distance of the needle tip to the center of collecting drum was adjusted to $18 \mathrm{~cm}$ and the needle gauge was 22. The process continued for $8 \mathrm{~h}$ and the fabricated mat was washed with methanol and distilled water for removal of residual DMF. Later, the nanofibrous membrane was dried for $10 \mathrm{~h}$ at $50 \pm 1$ ${ }^{\circ} \mathrm{C}$.

\section{Immobilization of laccase onto PAN-biochar membrane}

The membrane sample was cut into pieces of $9 \mathrm{~cm}^{2}$ and precisely weighed. They were immersed in $1 \mathrm{M} \mathrm{NaOH}(15 \mathrm{~mL})$ and kept at $40{ }^{\circ} \mathrm{C}$ for $1 \mathrm{~h}$. The samples were washed with ultrapure water until they reached neutral $\mathrm{pH}$. The samples were then immersed in $50 \mathrm{~mL}$ of $10 \% \mathrm{v} / \mathrm{v}$ $\mathrm{HNO}_{3} / \mathrm{H}_{2} \mathrm{SO}_{4}(50: 50 \mathrm{v} / \mathrm{v})$ and kept at $25{ }^{\circ} \mathrm{C}$ for 2 hours. In this process, $\mathrm{COOH}$ groups are formed onto PAN and biochar and the number of these groups were quantified by using a method described elsewhere ${ }^{1}$. The functionalized PAN/biochar samples were treated with 30 $\mathrm{mL}$ of $10 \%(\mathrm{v} / \mathrm{v})$ ethylenediamine at $25{ }^{\circ} \mathrm{C}$ for $1 \mathrm{~h}$ and then washed with MQ water. The modified samples were equilibrated with $10 \mathrm{~mL}$ of sodium phosphate buffer ( $\mathrm{pH} 7.0$ ) for $4 \mathrm{~h}$, rinsed and transferred to a $20 \mathrm{~mL}$ solution containing different amounts of glutaraldehyde $(2,4$, $6,8,10 \% \mathrm{v} / \mathrm{v}$ ) for 1 hour at $25^{\circ} \mathrm{C}$. The modified samples containing glutaraldehyde were washed 
thoroughly with $0.1 \mathrm{M}$ sodium phosphate buffer $(\mathrm{pH}$ 7.0). Finally, the activated samples were treated with $20 \mathrm{~mL}$ of enzyme solution $(1 \mathrm{~g} / \mathrm{L})$ for varied time periods $(2,5,10,15,20 \mathrm{~h}), \mathrm{pH}$ values $(2,3,4,5,6,7)$ and temperatures $\left(5,10,15,20,25^{\circ} \mathrm{C}\right)$. The immobilized laccase samples were then taken out and thoroughly rinsed with $0.1 \mathrm{M}$ solution of phosphate buffer. In Figure 1Error! Reference source not found., the processes involved in immobilization of laccase are illustrated.

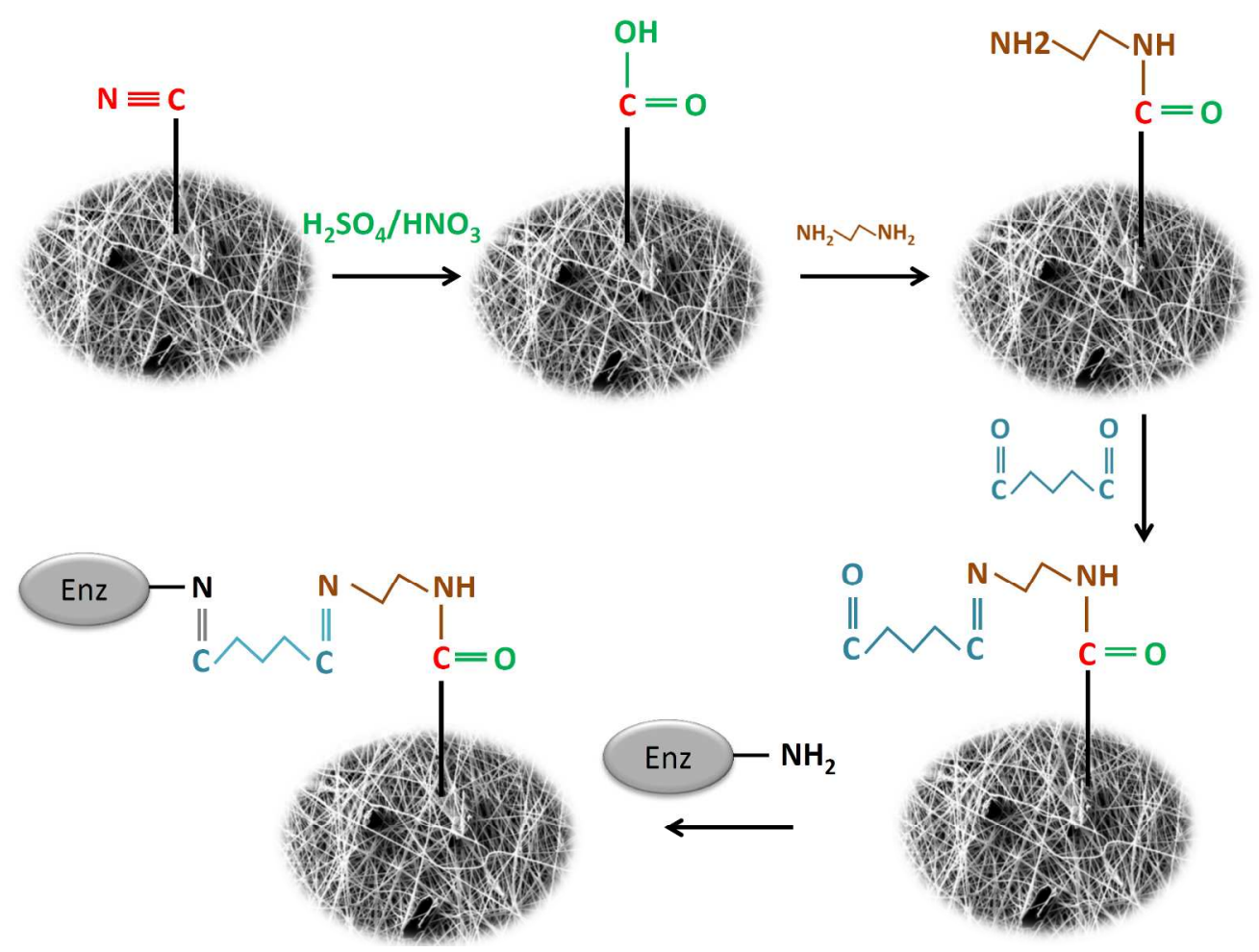

Figure 1: Immobilization of laccase on PAN-Biochar nanofibrous membrane

\section{Optimal pH and temperature}

For evaluation of optimal $\mathrm{pH}, 50 \mu \mathrm{L}$ of free laccase and $20 \mathrm{mg}$ of immobilized samples were added to separate tubes containing $3 \mathrm{~mL}$ of buffers at different $\mathrm{pH}$ levels (2 to 9) and incubated at $25^{\circ} \mathrm{C}$ and $200 \mathrm{rpm}$ for $24 \mathrm{~h}$. Later, the laccase activities of free and immobilized samples were measured at same $\mathrm{pH}$ (Section 2.4). For optimal temperature, samples were incubated at different temperatures $\left(20-70{ }^{\circ} \mathrm{C}\right)$ for $1 \mathrm{~h}$ at constant $\mathrm{pH}$ of 3.5 and then the activities were measured at the same temperature. 


\section{Enzyme stability}

To evaluate the storage stability of the immobilized laccase, samples of free and immobilized laccase were kept at $4{ }^{\circ} \mathrm{C}$ and $25{ }^{\circ} \mathrm{C}$ for two months and their laccase activity was measured for two months period. The measuring procedure was performed in triplicates and the average along with the standard deviation is presented in figures. The ANOVA, provided by Excel software, showed p-value less than 0.01 for each graph which confirmed that the changes in the laccase activity are directly related to changes in studied parameters i.e. $\mathrm{pH}$, temperature, time and number of cycles.

\section{Characterization of fabricated NFM}

The surface morphology of the fabricated NFM was examined using an EVO-50 (Zeiss, Germany) scanning electron microscope (SEM). The acceleration voltage was $10 \mathrm{kV}$ and prior to analysis, the sample was coated with a thin layer of gold using an SPI Module sputter coater.

\section{Biodegradation test}

The efficiency of immobilized laccase on PAN-biochar nanofibrous membrane for degradation of three PhACs as representatives of different categories of pharmaceutical compounds was investigated in batch mode. A $3 \times 3 \mathrm{~cm}^{-2}$ of prepared biocatalyst along with $50 \mathrm{~mL}$ aqueous solution containing CTC, CBZ and DCF concentration of $200 \mathrm{ppb}$ at different $\mathrm{pH}$ values $(4,5,6$ and 7) was added to a $100 \mathrm{~mL}$ flask and incubated at room temperature. Samples for measuring the concentrations of compounds in solution were taken at each 2-hour interval for 8 hours. Also, samples of biocatalyst were collected and a number of compounds adsorbed onto membrane were measured through desorption into methanol after $24 \mathrm{~h}$ of incubation at room temperature. The concentration of compounds was estimated by using Laser Diode Thermal Desorption (LDTD) (Phytronix technologies, Canada) coupled with an LCQ Duo ion trap tandem mass spectrometer (Thermo Finnigan, USA). The details of the analytical methods are described elsewhere ${ }^{13}$.

\section{Results and discussion}

Functionalization and immobilization 
In the first step of functionalization (Figure 1), carboxylic groups were formed on the surface of PAN-biochar nanofibrous membrane and the amount of these groups was quantified to be 5.6 $\mathrm{mmol} / \mathrm{g}$. Figure 2 demonstrates the SEM micrograph of PAN nanofibers with and without laccase immobilization. The surface of nanofibers before laccase immobilization is quite smooth but after immobilization, they showed a rough texture which may be due to the effect of acid treatment as well as binding of enzyme macromolecules. We already demonstrated that the entrapment of biochar particles into the nanofibers can increase the specific surface area of nanofibrous membrane to more than $12 \mathrm{~m}^{2} / \mathrm{g}$. These adsorbent particles can adsorb the micropollutants from solution and prepare enough time for degradation with laccase ${ }^{10}$.

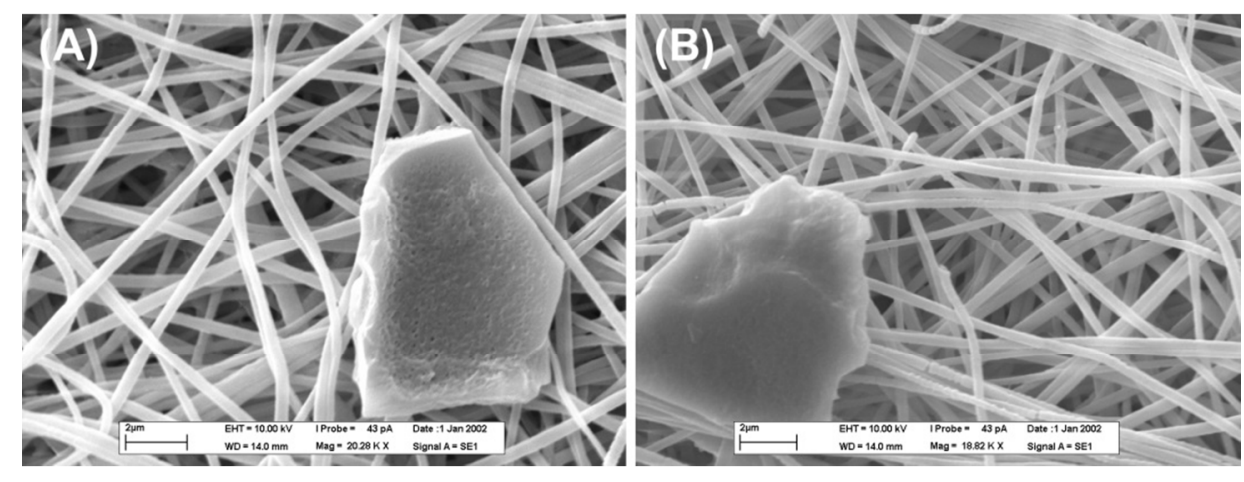

Figure 2: SEM micrographs of PAN nanofibers A: before laccase immobilization and B: after laccase immobilization

\section{Effect of process variables on immobilization}

An illustrative scheme for laccase immobilization on PAN-biochar nanofibrous membrane is shown in Figure 1. During the process, one of the amine groups in ethylenediamine reacts with the carboxylic group to make amide group and then the other amine group reacts with one of the aldehyde groups in glutaraldehyde. Finally, the other free aldehyde group reacts with amino groups in the enzyme to form imino group $(-\mathrm{CH}=\mathrm{N}-)$. The properties of the immobilized enzyme are significantly affected by the immobilization parameters and therefore it is important to discuss the importance of main variables in laccase immobilization. Laccase was immobilized for different times varying from $2 \mathrm{~h}$ to $20 \mathrm{~h}$ and the effect of time on the activity of immobilized laccase is illustrated in Figure 3-A. In this experiment, the temperature, $\mathrm{pH}$ and glutaraldehyde concentration were fixed at $5{ }^{\circ} \mathrm{C}, 4$ and $6 \%(\mathrm{v} / \mathrm{v})$, respectively. According to Figure $3-\mathrm{A}$, the 
maximum activity was obtained after 2 hours of reaction and then a sharp decline was observed in the activity. Jiang et al. immobilized laccase on chitosan microspheres and found that 2 hours of immobilization gave the highest activity which is accordance with the results of this research. They explained the sharp decline in activity after 2 hours by reducing the accessibility of the active sites to the substrate due to excessive immobilized enzyme molecules ${ }^{14}$. In a similar research, Trivedi et al. found that after two hours of contact time between enzyme and substrate, the activity of the immobilized enzyme is reduced and related this behavior to shear forces ${ }^{15}$. Also, Bayramoglu et al. observed a reduction in activity of chloroperoxidase after 9 hours of immobilization onto magnetic particles. They concluded that multipoint attachment of enzyme onto carrier and overcrowding of surface with enzyme molecules are the main reasons for activity reduction after a certain time ${ }^{16}$.

To understand the effect of temperature on immobilization, laccase was immobilized at different temperatures, varying from $5{ }^{\circ} \mathrm{C}$ to $25^{\circ} \mathrm{C}$. In this experiment, the values of glutaraldehyde concentration, $\mathrm{pH}$ and immobilization time were fixed at $6 \%(\mathrm{v} / \mathrm{v}), 4$ and $2 \mathrm{~h}$. The effect of temperature on laccase immobilization in terms of activity unit per gram support is shown in Figure 3-B. According to this figure, by increasing the temperature from $5{ }^{\circ} \mathrm{C}$ to $25{ }^{\circ} \mathrm{C}$, the immobilization efficiency decreased continuously from $12.7 \mathrm{U} / \mathrm{g}$ to $5.5 \mathrm{U} / \mathrm{g}$. Trivedi et al. ${ }^{15}$ and Liao and Chen ${ }^{17}$ observed same behavior for immobilization of alcohol dehydrogenases which indicated that low temperature was less detrimental to the enzyme during immobilization.

To determine the effect of glutaraldehyde concentration on immobilization, laccase was fixed on PAN-biochar nanofibrous membrane with different concentrations of glutaraldehyde ranging from $2 \%$ to $10 \%(\mathrm{v} / \mathrm{v})$. In this experiment, the temperature, $\mathrm{pH}$ and immobilization time were fixed at $5{ }^{\circ} \mathrm{C}, 4$ and $2 \mathrm{~h}$. As shown in Figure 3-C, the activity of immobilized enzyme increased from $5.39 \mathrm{U} / \mathrm{g}$ to $12.79 \mathrm{U} / \mathrm{g}$ by increasing the concentration of glutaraldehyde from $2 \%$ to $6 \%$ $(\mathrm{v} / \mathrm{v})$. It can be due to the insufficient aldehyde groups bonded to the surface and poor mechanical strength for keeping immobilized laccase at low concentrations of glutaraldehyde ${ }^{14}$. However, the activity of immobilized enzyme showed a decrease to $2.45 \mathrm{U} / \mathrm{g}$ by further increasing the concentration of glutaraldehyde to $10 \%(\mathrm{v} / \mathrm{v})$. It is reported that the extensive interaction of single enzyme macromolecules with aldehyde groups on the surface of the carrier can change the conformation of enzyme and decrease its activity ${ }^{14}$. 
Electrostatic interaction between enzyme and carrier, which in turn is affected by solution $\mathrm{pH}$, can influence the immobilization of laccase onto PAN-biochar nanofibrous membrane. In order to study the $\mathrm{pH}$ effect, immobilization was performed at different $\mathrm{pH}$ values, varying from 2 to 7 . In this experiment, values of temperature, glutaraldehyde concentration and immobilization time were fixed at $5{ }^{\circ} \mathrm{C}, 6 \%(\mathrm{v} / \mathrm{v})$ and $2 \mathrm{~h}$ and the results are illustrated in Figure 3-D. According to this figure, by increasing the $\mathrm{pH}$ from 2 to 4 , the activity was increased from $5.8 \mathrm{U} / \mathrm{g}$ to its maximum level i.e. $12.19 \mathrm{U} / \mathrm{g}$. By further increasing the $\mathrm{pH}$ level to 6 , the activity decreased continuously to $9.07 \mathrm{U} / \mathrm{g}$ and it remained constant by increasing $\mathrm{pH}$ to 7 . The values of the isoelectronic point - the $\mathrm{pH}$ at which the molecules carry no net electrical charge- for fungal laccase and PAN nanofibers are reported to be around 4 and 3.6, respectively ${ }^{18}$. Considering the values of isoelectronic points, one can conclude that at $\mathrm{pH}$ levels lower than 3.6 and greater than 4 , electrostatic repulsion happens between laccase and nanofibrous membrane and can reduce the enzyme loading on support ${ }^{19}$. Therefore, the maximum level of activity should be expected at $\mathrm{pH}$ range of 3.6-4.
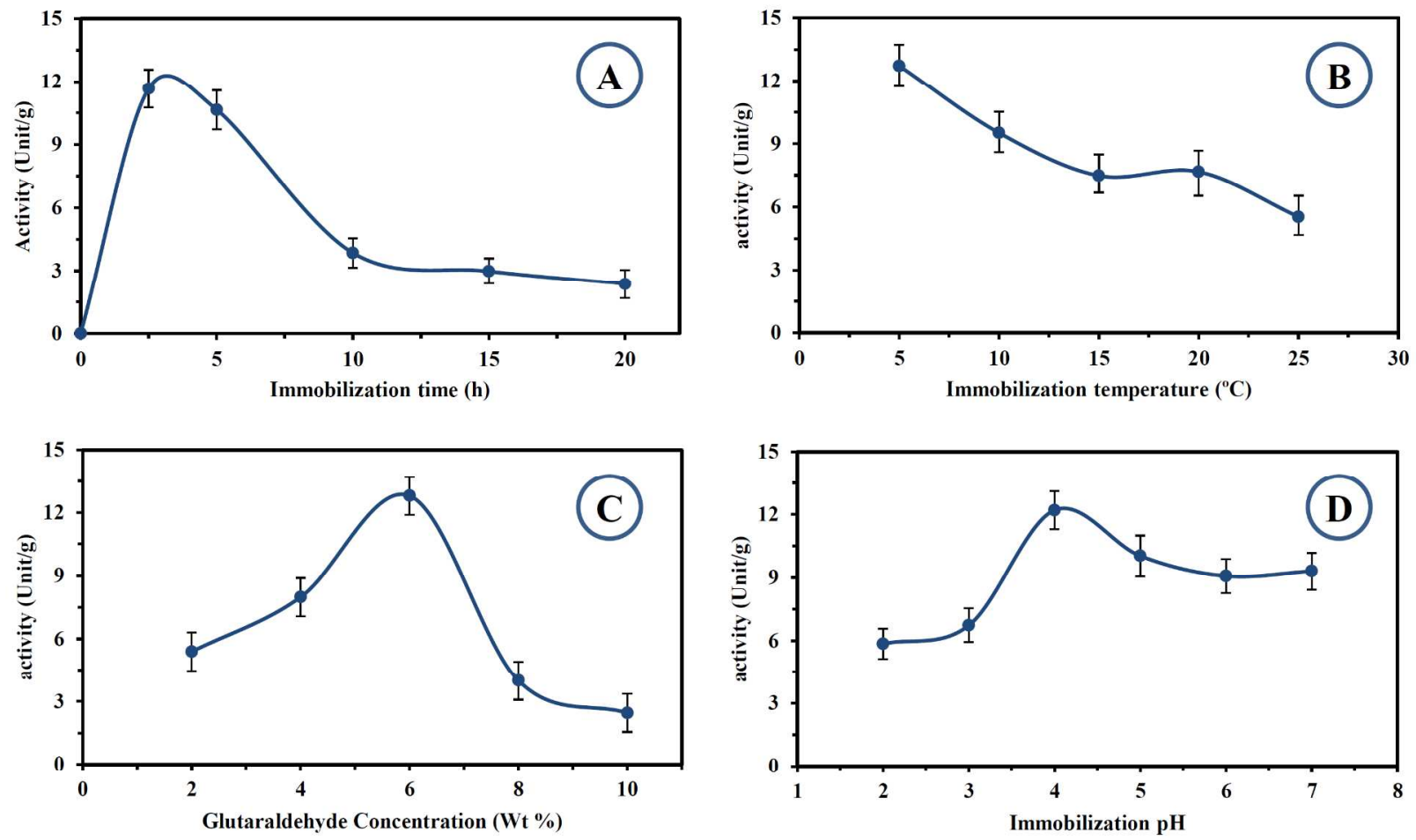

Figure 1: Effect of: a) time, b) temperature, c) glutaraldehyde concentration and d) $\mathrm{pH}$ on immobilization of laccase onto Polyacrylonitrile/biochar nanofibrous membrane 


\section{Effect of temperature and pH on laccase activity}

For evaluating the effect of $\mathrm{pH}$ and temperature, a sample was fabricated at optimized immobilization conditions discussed in section 3.2. The $\mathrm{pH}$ dependence of activity of free and immobilized laccase under optimized conditions is shown in Figure 4-A. The optimal $\mathrm{pH}$ for free laccase was between 4 and 5 while for immobilized laccase, it was between 3 and 4 . The unequal partitioning of $\mathrm{OH}^{-}$and $\mathrm{H}^{+}$concentrations in the microenvironment of the immobilized enzyme and the bulk solution often causes a displacement in the optimal $\mathrm{pH}$ toward more acidic values 20. In this work, it seemed that biochar and the cross-links affected the partitioning of $\mathrm{H}+$ and $\mathrm{OH}^{-}$and shifted the optimum $\mathrm{pH}$ for immobilized enzyme to lower values. Wang et al., reported that the optimum $\mathrm{pH}$ for maximal activity of laccase shifted from 3.5 for free laccase to 4 for immobilized laccase onto PAN membrane with metal chelation due to electrostatic interactions between career and enzyme ${ }^{21}$. In contrast, $\mathrm{Xu}$ et al. ${ }^{22}$ and Catapane et al. ${ }^{23}$ observed no changes in optimum $\mathrm{pH}$ of immobilized laccase onto PAN nanofibers through amidination and diazotization processes and related it to the neutral nature of cross-links and zero surfaces electric charge of PAN. Furthermore, the immobilized laccase in this work showed a lower sensitivity to $\mathrm{pH}$ in the acidic range which can be due to the multi-point attachments of enzyme and nanofibers which protect the enzyme from deactivation ${ }^{24}$.

The effect of temperature on the activity of free and immobilized laccase is illustrated in Figure 4-B. The optimal temperature for both free and immobilized enzyme was around $35{ }^{\circ} \mathrm{C}$. However, immobilized laccase showed higher stability at temperatures higher than optimal temperature so that at $70{ }^{\circ} \mathrm{C}$, free laccase retained $19 \%$ of its maximum activity, while immobilized laccase retained $50 \%$ of its maximum activity. The multipoint attachment and interactions between laccase and membrane reduced the conformational changes at a higher temperature and protected laccase from deactivation. Therefore, the optimum temperature can be shifted to higher values ${ }^{9 b}$. The reported effects of temperature on the stability of laccase in literature are not in accordance with each other. For instance, although many researchers reported a slight improvement in thermal stability of immobilized laccase (20-45\%) ${ }^{21,25}$, Jiang et al. observed higher sensitivity of laccase after immobilization onto chitosan compared to free laccase (up to $65 \%)^{14}$. 
(A)

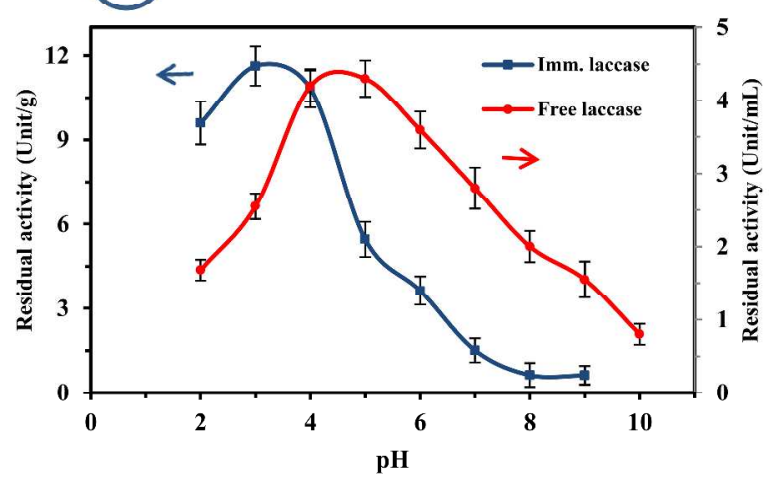

B

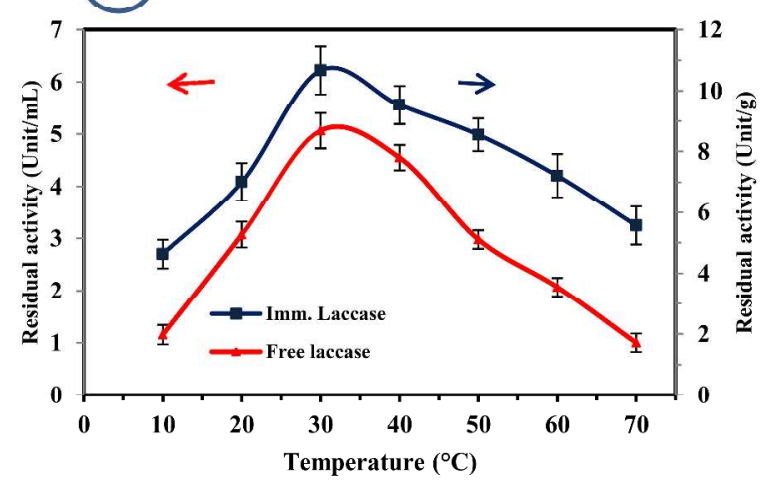

Figure 2: Effect of: A) pH; and B) temperature on activity of the free and immobilized laccase

\section{Storage Stability of immobilized laccase}

The denaturation of the enzyme is a natural phenomenon that happens over a period of time and results in the depletion of enzymatic activity. Immobilization can restrict the macromolecules and increase their stability ${ }^{26}$. Figure 5-A illustrates the residual activity of free and immobilized enzymes stored at $25 \pm 1{ }^{\circ} \mathrm{C}$ and $4 \pm 1{ }^{\circ} \mathrm{C}$. Accordingly, the immobilized enzymes showed more than $10 \%$ and $94 \%$ of their initial activities after 30 days, while the free enzymes showed only $1 \%$ and $32 \%$ of their initial activities. It indicated that laccase immobilization on PAN-biochar nanofibrous membrane can enhance the storage stability of biocatalyst. This enhancement is due to the restriction of enzyme conformational changes ${ }^{9 b}$. Similar results for immobilized enzymes on PAN after 20 days of storage at $4 \pm 1{ }^{\circ} \mathrm{C}$ were reported by Feng et al. $(52 \%){ }^{9 b}$, Wang et al. $(50 \%)^{21}$ and Zhang et al. $(60 \%)^{27}$. Xu et al. immobilized laccase on chitosan nanofibers and observed $60 \%$ residual activity after 10 days of storage at ambient temperature, while free laccase showed no activity after 10 days ${ }^{28}$. In a related study, Jiang et al. immobilized laccase onto chitosan microspheres and reported $70 \%$ of initial activity after 30 days storage at $4 \pm 1{ }^{\circ} \mathrm{C}$, while the free enzyme retained $30 \%$ of its initial activity ${ }^{14}$.

\section{Operational stability of immobilized laccase}

Free laccase is soluble in aqueous reaction media and consequently, its discharge with product flow increases the cost of operation. In contrast, immobilized laccase can be reused which in turn decreases the operational cost for practical application. However, denaturation during the process decreases the enzyme activity during repeated usage of the enzyme. Hence, understanding the 
behavior of immobilized laccase during repeated usage is important for its industrial application. In this research, the operational stability of immobilized laccase was determined by reusing and monitoring the activity of the same immobilized laccase sample for 10 successive cycles of ABTS oxidation. Each run was performed for $3 \mathrm{~min}$ and the activity of the sample was measured in each cycle and the results are illustrated in Figure 5-B. From first to the third run, there is a sharp reduction of activity (52\%) and in next 7 cycles, 30\% reduction was observed in the activity. The sharp decrease in the activity of laccase is expected due to leaching of some enzyme molecules or denaturation of enzymes as many researchers reported the same behavior 16,27. For example, Xu et al. immobilized laccase onto PAN nanofibers through covalent bonding (amidination) and reported around $40 \%$ of activity reduction after 10 cycles ${ }^{22}$. In a related research, Feng et al. immobilized laccase onto PAN nanofibers and observed $35 \%$ reduction in laccase activity after 10 cycles of usage ${ }^{25}$. Denaturation of laccase may happen due to the formation of radicals during the reaction with ABTS which can block the enzyme active sites ${ }^{29}$.
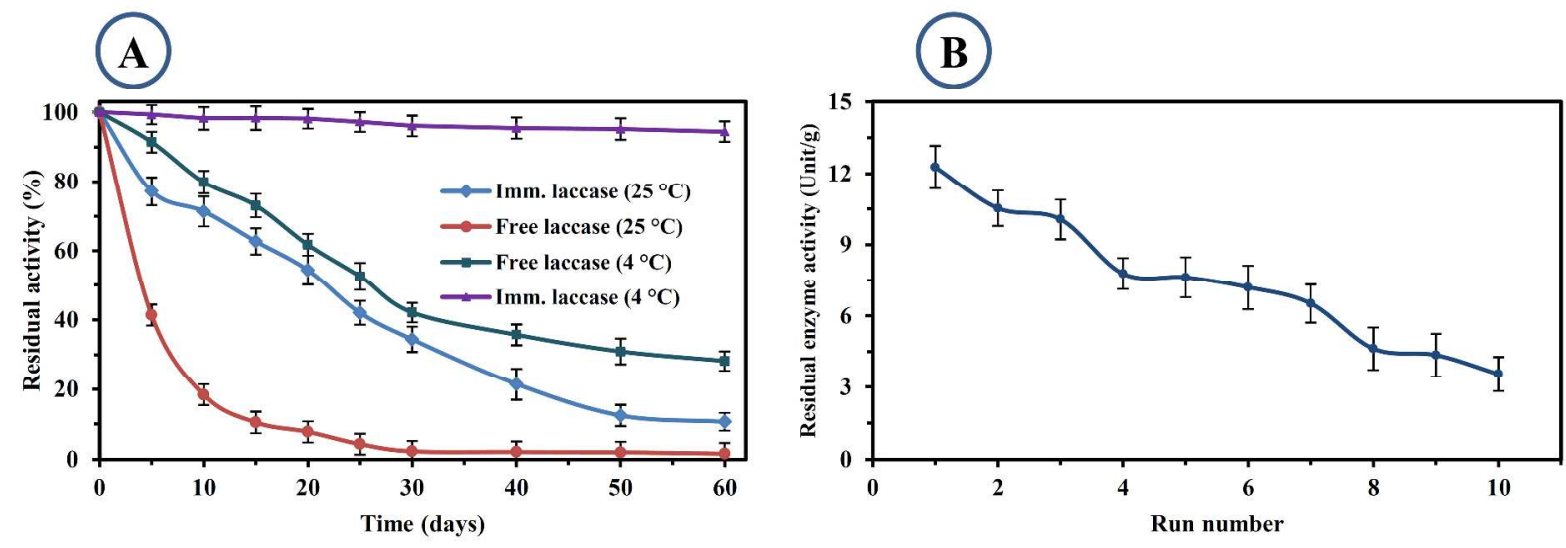

Figure 3: A) Storage stability of free and immobilized laccases at different temperatures and; B) reusability of immobilized laccase

\section{Biodegradation of pharmaceutical compounds}

Laccase is an oxidoreductase enzyme known for non-specific oxidation of organic compounds. The generation of free radicals through four copper ions in laccase is considered as the main mechanism for attacking the organic molecules ${ }^{8 a}$. In this research, the immobilized laccase onto composite electrospun membrane was employed for degradation of a mixture of three pharmaceutical compounds CTC, CBZ and DCF in different $\mathrm{pH}$ values. According to the values 
of octanol water partitioning coefficients (Kow), CTC, CBZ, and DCF with Kow values of -3.6, 2.45 and 4.51 are highly hydrophilic, moderately hydrophilic and hydrophobic, respectively which affect their interaction with membrane and biochar. The concentration of each compound in solution was set to $200 \mathrm{ppb}$ since the reported concentrations in literature ranged from several ppb levels in municipal wastewater ${ }^{30}$ to several ppm in pharmaceutical industries effluent ${ }^{31}$. The results of biodegradation tests are presented in Figure 4. Accordingly, the concentrations of three compounds were reduced gradually during the reaction and the maximum removal of all compounds appeared at $\mathrm{pH}$ 5. It indicates that such an enzymatic treatment can be useful for neutral to slightly acidic water and wastewater sources. In drinking water treatment plants and municipal wastewater treatment plants, the $\mathrm{pH}$ value of influent streams falls within the range of 6-8 and hence this system has a potential to treat these sources of water. 

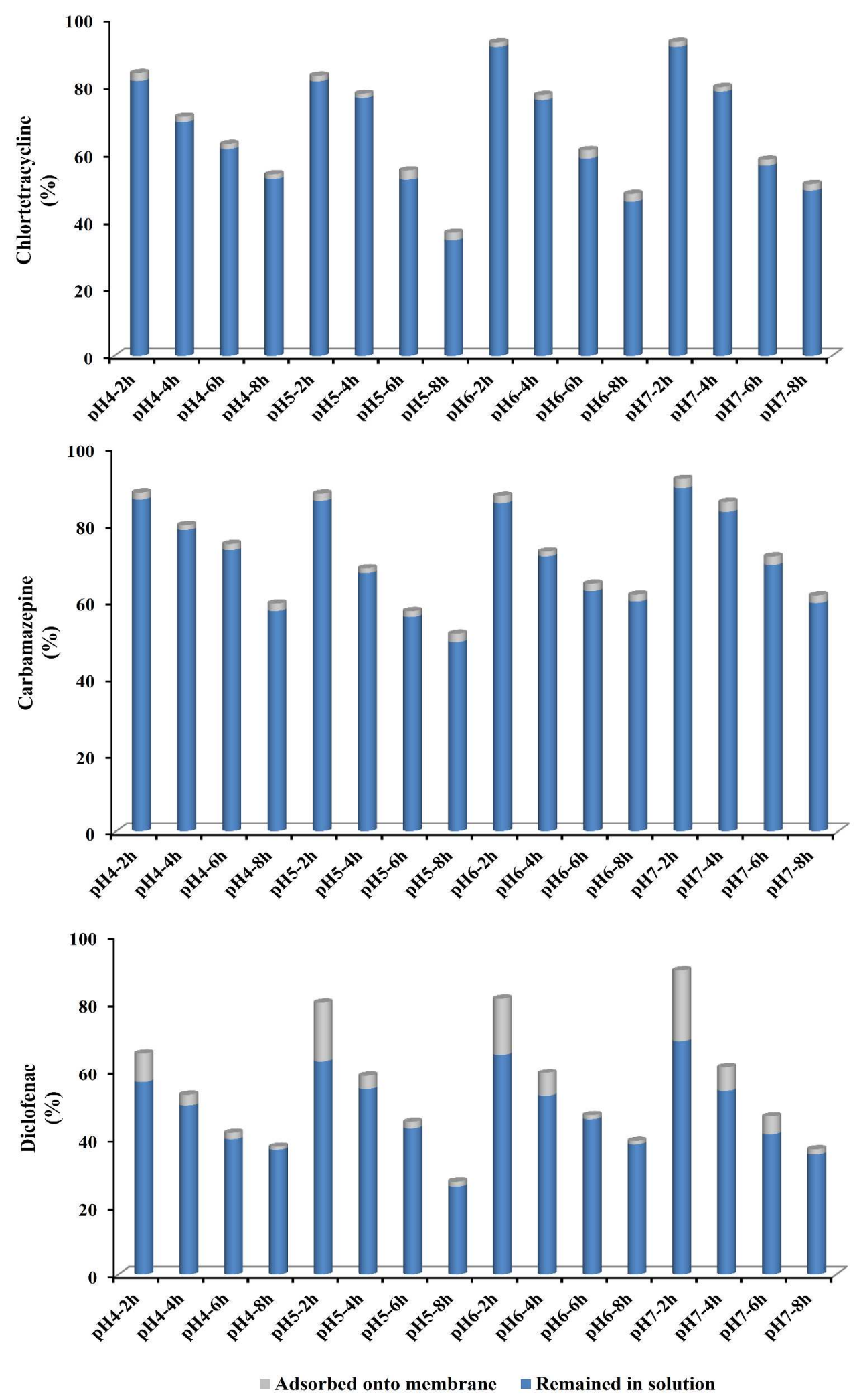

Figure 4: Biodegradation of pharmaceutical compounds using immobilized laccase 
DCF had the maximum degradation efficiency of $72.7 \%$ followed by CTC with $63.3 \%$ and CBZ with $48.6 \%$ degradation efficiency. Sathishkumar et al. and $\mathrm{Xu}$ et al. used immobilized laccase for degradation of DCF in batch mode and observed complete removal after $5 \mathrm{~h}$ and $6 \mathrm{~h}$ respectively $^{32}$. Also, De Cazes et al. employed immobilized laccase onto the ceramic membrane and observed $56 \%$ degradation efficiency for tetracycline after $24 \mathrm{~h}{ }^{9 a}$. However, they used high concentration $(>12 \mathrm{ppm})$ of target compound which is far beyond the environmentally relevant concentrations of pharmaceutical compounds and it is hardly possible to extrapolate the data to lower concentrations. There are also several reports in the literature on integration of adsorbents such as montmorillonite and graphene oxide into nanofibers for laccase immobilization to degrade the micropollutants. It was confirmed that addition of adsorbent improved the removal efficiency ${ }^{33}$. However, the capacity of adsorbents and the regenerative effect of laccase were not investigated in those research works. In this study, comparing the adsorption of target compounds on the membrane showed that CTC and CBZ, which are considered hydrophilic, did not significantly adsorb onto membrane $(<3 \%)$ while DCF which is a hydrophobic compound was significantly adsorbed (up to $21 \%$ ) in the beginning of reactions ( $\mathrm{p}$-value $<0.01$ ). However, the decreasing trend of adsorption extent during reaction time was observed for all compounds and almost for all $\mathrm{pH}$ values which confirmed the regeneration of adsorption sites of biochar by the action of laccase. In real world applications, such as tertiary treatment stage of the wastewater treatment plants, this regeneration capability is very important due to the continuous large flow of the micropollutants through the stage. Furthermore, the capacity of adsorption, the blockage of adsorption sites by non-degradable species and the kinetics of regeneration in real wastewater effluent should be investigated before considering this treatment method for large scale application.

\section{Conclusion}

Laccase, obtained from Trametes versicolor, was covalently immobilized onto a nanofibrous membrane made by entrapment of activated biochar into PAN nanofiber through electrospinning. The obtained biocatalyst showed the enzyme loading of $12.7 \mathrm{U} / \mathrm{g}$ and it was used for degradation of three representative pharmaceutical compounds, namely i.e. CTC, CBZ, and DCF. Compared to free laccase, the stability of immobilized laccase in terms of tolerating high temperature, acidic $\mathrm{pH}$, and long-term storage was improved by up to $32 \%, 43 \%$ and $66 \%$, respectively. 
Employing immobilized laccase for degradation of three pharmaceutical compounds exhibited $72.7 \%, 63.3 \%$ and $48.6 \%$ degradation efficiency for DCF, CTC, and CBZ, respectively after 8 hours of reaction. The decreasing trend of adsorption extent during reaction time for all compounds confirmed the regenerative effect of laccase on adsorption sites of biochar.

\section{Acknowledgements}

The authors are sincerely thankful to the Natural Sciences and Engineering Research Council of Canada (Discovery Grant 355254 and Strategic Grants), and Ministère des Relations Internationales du Québec (122523) (coopération Québec-Catalanya 2012-2014) for financial support. INRS-ETE is thanked for providing Mr. Mehrdad Taheran "Bourse excellence" scholarship for his Ph.D. studies. The views or opinions expressed in this article are those of the authors.

\section{References}

1. Naghdi, M.; Taheran, M.; Brar, S. K.; Kermanshahi-pour, A.; Verma, M.; Surampalli, R. Y., Immobilized laccase on oxygen functionalized nanobiochars through mineral acids treatment for removal of carbamazepine. Sci. Total Environ. 2017, 584-585, 393-401. DOI: 10.1016/j.scitotenv.2017.01.021

2. Nunes, B.; Antunes, S. C.; Gomes, R.; Campos, J. C.; Braga, M. R.; Ramos, A. S.; Correia, A. T., Acute Effects of Tetracycline Exposure in the Freshwater Fish Gambusia holbrooki: Antioxidant Effects, Neurotoxicity and Histological Alterations. Arch. Environ. Contam. Toxicol. 2015, 68 (2), 371-381. DOI: 10.1007/s00244-014-0101-z

3. (a) Li, D.; Yu, T.; Zhang, Y.; Yang, M.; Li, Z.; Liu, M.; Qi, R., Antibiotic Resistance Characteristics of Environmental Bacteria from an Oxytetracycline Production Wastewater Treatment Plant and the Receiving River. Appl. Environ. Microbiol. 2010, 76 (11), 3444-3451. DOI: 10.1128/aem.02964-09 ; (b) Tao, R.; Ying, G.-G.; Su, H.-C.; Zhou, H.-W.; Sidhu, J. P. S., Detection of antibiotic resistance and tetracycline resistance genes in Enterobacteriaceae isolated from the Pearl rivers in South China. Environ. Pollut. 2010, 158 (6), 2101-2109. DOI: 10.1016/j.envpol.2010.03.004

4. Taheran, M.; Brar, S. K.; Verma, M.; Surampalli, R. Y.; Zhang, T. C.; Valero, J. R., Membrane processes for removal of pharmaceutically active compounds (PhACs) from water and wastewaters. Sci. Total Environ. 2016, 547, 60-77. DOI: 10.1016/j.scitotenv.2015.12.139

5. (a) Chang, P. H.; Li, Z.; Jean, J. S.; Jiang, W. T.; Wang, C. J.; Lin, K. H., Adsorption of tetracycline on 2:1 layered non-swelling clay mineral illite. Appl. Clay. Sci. 2012, 67-68, 158163. DOI: 10.1016/j.clay.2011.11.004 ; (b) Gómez-Pacheco, C. V.; Sánchez-Polo, M.; RiveraUtrilla, J.; López-Peñalver, J., Tetracycline removal from waters by integrated technologies based on ozonation and biodegradation. Chem. Eng. J. 2011, 178 (0), 115-121. DOI: 10.1016/j.cej.2011.10.023 
6. Marco-Urrea, E.; Pérez-Trujillo, M.; Vicent, T.; Caminal, G., Ability of white-rot fungi to remove selected pharmaceuticals and identification of degradation products of ibuprofen by Trametes versicolor. Chemosphere 2009, 74 (6), 765-772. DOI: 10.1016/j.chemosphere.2008.10.040

7. Tran, N. H.; Urase, T.; Kusakabe, O., Biodegradation Characteristics of Pharmaceutical Substances by Whole Fungal Culture Trametes versicolor and its Laccase. J. water environ. technol. 2010, 8 (2), 125-140. DOI: 10.2965/jwet.2010.125

8. (a) Lloret, L.; Eibes, G.; Lú-Chau, T. A.; Moreira, M. T.; Feijoo, G.; Lema, J. M., Laccase-catalyzed degradation of anti-inflammatories and estrogens. Biochem. Eng. J. 2010, 51 (3), 124-131. DOI: 10.1016/j.bej.2010.06.005 ; (b) Spina, F.; Cordero, C.; Schilirò, T.; Sgorbini, B.; Pignata, C.; Gilli, G.; Bicchi, C.; Varese, G. C., Removal of micropollutants by fungal laccases in model solution and municipal wastewater: evaluation of estrogenic activity and ecotoxicity. J. Clean. Prod. 2015, 100, 185-194. DOI: 10.1016/j.jclepro.2015.03.047

9. (a) de Cazes, M.; Belleville, M. P.; Petit, E.; Llorca, M.; Rodríguez-Mozaz, S.; de Gunzburg, J.; Barceló, D.; Sanchez-Marcano, J., Design and optimization of an enzymatic membrane reactor for tetracycline degradation. Catal. Today 2014, 236, Part A, 146-152. DOI: 10.1016/j.cattod.2014.02.051 ; (b) Feng, Q.; Wei, Q.; Hou, D.; Bi, S.; Wei, A.; Xu, X., Preparation of amidoxime polyacrylonitrile nanofibrous membranes and their applications in enzymatic membrane reactor. J Eng. Fiber. Fabr. 2014, 9 (2), 146-152. DOI:

10. Taheran, M.; Naghdi, M.; Brar, S. K.; Knystautas, E.; Verma, M.; Surampalli, R. Y.; Valero, J. R., Development of adsorptive membranes by confinement of activated biochar into electrospun nanofibers. Beilstein. J. Nanotechnol. 2016, 7, 1556-1563. DOI: 10.3762/bjnano.7.149

11. O’Connor, S.; Aga, D. S., Analysis of tetracycline antibiotics in soil: Advances in extraction, clean-up, and quantification. TrAC, Trends Anal. Chem. 2007, 26 (6), 456-465. DOI: 10.1016/j.trac.2007.02.007

12. Taheran, M.; Naghdi, M.; Brar, S. K.; Knystautas, E. J.; Verma, M.; Ramirez, A. A.; Surampalli, R. Y.; Valero, J. R., Adsorption study of environmentally relevant concentrations of chlortetracycline on pinewood biochar. Sci. Total Environ. 2016, 571, 772-777. DOI: 10.1016/j.scitotenv.2016.07.050

13. (a) Pulicharla, R.; Das, R. K.; Brar, S. K.; Drogui, P.; Sarma, S. J.; Verma, M.; Surampalli, R. Y.; Valero, J. R., Toxicity of chlortetracycline and its metal complexes to model microorganisms in wastewater sludge. Sci. Total Environ. 2015, 532, 669-675. DOI: 10.1016/j.scitotenv.2015.05.140 ; (b) Lonappan, L.; Pulicharla, R.; Rouissi, T.; Brar, S. K.; Verma, M.; Surampalli, R. Y.; Valero, J. R., Diclofenac in municipal wastewater treatment plant: quantification using laser diode thermal desorption - atmospheric pressure chemical ionizationtandem mass spectrometry approach in comparison with an established liquid chromatographyelectrospray ionization-tandem mass spectrometry method. J. Chromatogr. A 2016, 1433, 106113. DOI: 10.1016/j.chroma.2016.01.030 ; (c) Mohapatra, D. P.; Brar, S. K.; Tyagi, R. D.; Picard, P.; Surampalli, R. Y., Carbamazepine in municipal wastewater and wastewater sludge: Ultrafast quantification by laser diode thermal desorption-atmospheric pressure chemical ionization coupled with tandem mass spectrometry. Talanta 2012, 99, 247-255. DOI: 10.1016/j.talanta.2012.05.047

14. Jiang, D.-S.; Long, S.-Y.; Huang, J.; Xiao, H.-Y.; Zhou, J.-Y., Immobilization of Pycnoporus sanguineus laccase on magnetic chitosan microspheres. Biochem. Eng. J. 2005, 25 (1), 15-23. DOI: 10.1016/j.bej.2005.03.007 
15. Trivedi, A.; Heinemann, M.; Spiess, A. C.; Daussmann, T.; Büchs, J., Optimization of adsorptive immobilization of alcohol dehydrogenases. J. Biosci. Bioeng. 2005, 99 (4), 340-347. DOI: $10.1263 / \mathrm{jbb} .99 .340$

16. Bayramoğlu, G.; Kiralp, S.; Yilmaz, M.; Toppare, L.; Arıca, M. Y., Covalent immobilization of chloroperoxidase onto magnetic beads: Catalytic properties and stability. Biochem. Eng. J. 2008, 38 (2), 180-188. DOI: 10.1016/j.bej.2007.06.018

17. Liao, M.-H.; Chen, D.-H., Immobilization of yeast alcohol dehydrogenase on magnetic nanoparticles for improving its stability. Biotechnol. Lett 2001, 23 (20), 1723-1727. DOI: 10.1023/a:1012485221802

18. (a) Baldrian, P., Fungal laccases - occurrence and properties. FEMS Microbiology Reviews 2006, 30 (2), 215-242. DOI: 10.1111/j.1574-4976.2005.00010.x ; (b) Deng, S.; Bai; Chen, J. P., Aminated Polyacrylonitrile Fibers for Lead and Copper Removal. Langmuir 2003, 19 (12), 5058-5064. DOI: 10.1021/la034061x

19. Ahn, M.-Y.; Zimmerman, A. R.; Martínez, C. E.; Archibald, D. D.; Bollag, J.-M.; Dec, J., Characteristics of Trametes villosa laccase adsorbed on aluminum hydroxide. Enzyme Microb. Technol. 2007, 41 (1), 141-148. DOI: 10.1016/j.enzmictec.2006.12.014

20. Martino, A.; Pifferi, P. G.; Spagna, G., Immobilization of $\beta$-glucosidase from a commercial preparation. Part 2. Optimization of the immobilization process on chitosan. Process Biochem. 1996, 31 (3), 287-293. DOI: 10.1016/0032-9592(95)00066-6

21. Wang, Q.; Cui, J.; Li, G.; Zhang, J.; Huang, F.; Wei, Q., Laccase immobilization by chelated metal ion coordination chemistry. Polymers 2014, 6 (9), 2357-2370. DOI: 10.3390/polym6092357

22. Xu, R.; Chi, C.; Li, F.; Zhang, B., Laccase-polyacrylonitrile nanofibrous membrane: highly immobilized, stable, reusable, and efficacious for 2, 4, 6-Trichlorophenol removal. ACS Appl. Mater. Interfaces 2013, 5 (23), 12554-12560. DOI: 10.1021/am403849q

23. Catapane, M.; Nicolucci, C.; Menale, C.; Mita, L.; Rossi, S.; Mita, D. G.; Diano, N., Enzymatic removal of estrogenic activity of nonylphenol and octylphenol aqueous solutions by immobilized laccase from Trametes versicolor. J. Hazard. Mater. 2013, 248, 337-346. DOI: 10.1016/j.jhazmat.2013.01.031

24. Nguyen, L. N.; Hai, F. I.; Dosseto, A.; Richardson, C.; Price, W. E.; Nghiem, L. D., Continuous adsorption and biotransformation of micropollutants by granular activated carbonbound laccase in a packed-bed enzyme reactor. Bioresour. Technol. 2016, 210, 108-116. DOI: 10.1016/j.biortech.2016.01.014

25. Feng, Q.; Wu, D.; Huan, S.; Li, M.; Li, X., Study on the Preparation of the AOPAN/MMT Composite Nanofibers and Their Application for Laccase Immobilization. $J$. Eng. Fabr. Fiber. 2016, 11 (3). DOI:

26. Leonowicz, A.; Sarkar, J. M.; Bollag, J.-M., Improvement in stability of an immobilized fungal laccase. Appl. Microbiol. Biotechnol. 1988, 29 (2), 129-135. DOI: 10.1007/BF01982891

27. Zhang, P.; Wang, Q.; Zhang, J.; Li, G.; Wei, Q., Preparation of amidoxime-modified polyacrylonitrile nanofibers immobilized with laccase for dye degradation. Fiber. Polym. 2014, 15 (1), 30-34. DOI: 10.1007/s12221-014-0030-5

28. Xu, R.; Zhou, Q.; Li, F.; Zhang, B., Laccase immobilization on chitosan/poly (vinyl alcohol) composite nanofibrous membranes for 2, 4-dichlorophenol removal. Chem. Eng. J. 2013, 222, 321-329. DOI: 10.1016/j.cej.2013.02.074

29. Purich, D. L., Enzyme kinetics: catalysis and control: a reference of theory and bestpractice methods. Elsevier: 2010. 
30. Kim, S.; Eichhorn, P.; Jensen, J. N.; Weber, A. S.; Aga, D. S., Removal of Antibiotics in Wastewater: Effect of Hydraulic and Solid Retention Times on the Fate of Tetracycline in the Activated Sludge Process. Environ. Sci. Technol. 2005, 39 (15), 5816-5823. DOI: $10.1021 / \mathrm{es} 050006 \mathrm{u}$

31. Hou, J.; Wang, C.; Mao, D.; Luo, Y., The occurrence and fate of tetracyclines in two pharmaceutical wastewater treatment plants of Northern China. Environ. Sci. Pollut. Res. 2016, 23 (2), 1722-1731. DOI: 10.1007/s11356-015-5431-5

32. (a) Xu, R.; Tang, R.; Zhou, Q.; Li, F.; Zhang, B., Enhancement of catalytic activity of immobilized laccase for diclofenac biodegradation by carbon nanotubes. Chem. Eng. J. 2015, 262, 88-95. DOI: 10.1016/j.cej.2014.09.072 ; (b) Sathishkumar, P.; Chae, J.-C.; Unnithan, A. R.; Palvannan, T.; Kim, H. Y.; Lee, K.-J.; Cho, M.; Kamala-Kannan, S.; Oh, B.-T., Laccasepoly(lactic-co-glycolic acid) (PLGA) nanofiber: Highly stable, reusable, and efficacious for the transformation of diclofenac. Enzyme Microb. Technol. 2012, 51 (2), 113-118. DOI: 10.1016/j.enzmictec.2012.05.001

33. (a) Li, G.; Nandgaonkar, A. G.; Lu, K.; Krause, W. E.; Lucia, L. A.; Wei, Q., Laccase immobilized on PAN/O-MMT composite nanofibers support for substrate bioremediation: a de novo adsorption and biocatalytic synergy. RSC Advances 2016, 6 (47), 41420-41427. DOI: 10.1039/C6RA00220J ; (b) Wang, Q.; Cui, J.; Li, G.; Zhang, J.; Li, D.; Huang, F.; Wei, Q., Laccase Immobilized on a PAN/Adsorbents Composite Nanofibrous Membrane for Catechol Treatment by a Biocatalysis/Adsorption Process. Molecules 2014, 19 (3), 3376. DOI: 


\section{Page 21 of 21 ACS Sustainable Chemistry \& Engineering}

Synopsis: : Ligninolytic enzymes bound compounds at mild operational conditions without formation of harmful by-products. 